УДК:81'373,44-161.2Котляревський «Енеїда»

DOI https://doi.org/10.26661/2414-1135-2021-83-3

\title{
ГРАМАТИЧНІ АРХАЇЗМИ В «ЕНЕЇДІ» ІВАНА КОТЛЯРЕВСЬКОГО В АСПЕКТІ ІСТОРІЇ УКРАЇНСЬКОЇ ЛІТЕРАТУРНОЇ МОВИ
}

\author{
Барташук О. Ю. \\ кандидатка історичних наук, дочентка, \\ дочентка кафедри української мови та літератури \\ Хмельнииька гуманітарно-педагогічна академія \\ вул. Проскурівського підпілля, 139, Хмельницький, Україна \\ orcid.org/0000-0002-9022-5523 \\ olesya10091@ukr.net \\ Філінюк В. А. \\ кандидатка філологічних наук, дочентка, \\ дочентка кафедри української мови та літератури \\ Хмельницька гуманітарно-педагогічна академія \\ вул. Проскурівського підпілля, 139, Хмельницький, Україна \\ orcid.org/0000-0003-4951-7732 \\ amicus.solaris@gmail.com
}

Ключові слова: архаӥчні риси, лексико-фонетичні явищиа, лексико-словотвірні одиниці, лексико-морфологічні явища, застарілі форми.
У статті проаналізовано функціонування граматичних архаїзмів в «Енеїді» I. Котляревського на основі поділу на лексико-фонетичні, лексико-словотвірні та лексико-морфологічні. До частотних лексикофонетичних архаїчних явищ належать чергування звуків; фонетичні форми зі збереженням звука, замість якого в сучасній мові виступає інший; вставляння, усічення, випадання одного або кількох звуків; неповноголосся -ра-, -ла-, що відповідає сучасному -оро-, -оло-, відсутність протези.

Серед словотвірно-лексичних архаїчних явищ виділено ті, що пов’ язані 3 уживанням префіксів іс-, із-, в-, во-, воз-, вос, у-, од-, со-, су-; суфіксів -ець- та -ник-; компонента много. 3'ясовано, що в «Енеїді» часто трапляються лексико-морфологічні архаїчні явища, пов'язані 3 уживанням застарілої дієслівної особової форми теперішнього часу єсть; суфікса -ова- замість -ува-, -юва-; архаїчних інфінітивних форм на -ть; форм особових дієслів без закінчення; використанням постфікса -ся в дієслівних формах; форм наказового способуз нередукованим закінченням -іте та -ім; особових дієслівних форм зворотного стану із суфіксом -сь замість -ся; постфікса -ть у формі III особи однини теперішнього часу; архаїчних форм дієприкметників і дієприслівників; паралелізмом особових закінчень дієслів у I особі множини: -мъ, -мо, -мы, -м, -ме, що розвинулися після занепаду зредукованих.

До поширених лексико-морфологічних архаїчних явищ у системі іменника належать уживання застарілих іменникових форм зі специфічними закінченнями й суфіксами; у системі прикметника уживання нестягнених повних форм прикметників (дієприкметників, порядкових числівників, вказівних, означальних і питально-відносних займенників); наявність стягнених прикметникових, дієприкметникових і займенникових форм; архаїчні відмінкові форми прикметників; творення складної форми ступенів порівняння прикметників за допомогою слів «самий», «тяжко», «з диявола» та суфікса -ійш-. Виділено архаїчні форми займенників, прислівників і службових частин мови, які вийшли 3 активного вжитку чи збереглися в говорах. 


\title{
GRAMMATICAL ARCHAISMS IN IVAN KOTLIAREVSKYI'S "ENEIDA" IN THE ASPECT OF THE HISTORY OF THE UKRAINIAN LITERARY LANGUAGE
}

\author{
Bartashuk O. Yu. \\ Candidate of Historical Sciences, Associate Professor, \\ Associate Professor at the Department of Ukrainian Language and Literature \\ Khmelnytsky Humanitarian-Pedagogical Academy \\ Proskurivskoho pidpillia str., 139, Khmelnytsky, Ukraine \\ orcid.org/0000-0002-9022-5523 \\ olesya10091@ukr.net
}

Filiniuk V. A.

Candidate of Philological Sciences, Associate Professor, Associate Professor at the Department of English Philology

Khmelnytsky Humanitarian-Pedagogical Academy

Proskurivskoho pidpillia str., 139, Khmelnytsky, Ukraine

orcid.org/0000-0003-4951-7732

amicus.solaris@gmail.com

Key words: archaic features, lexical-phonetic phenomena, lexical-word-forming units, lexical-morphological phenomena, obsolete forms.
The article analyzes the functioning of grammatical archaisms in I. Kotliarevskoho "Eneida" on the basis of division into lexico-phonetic, lexico-word-forming and lexico-morphological types. Frequent lexical-phonetic archaic phenomena include alternation of sounds; phonetic forms with the preservation of sound, which is replaced by another in modern language; inserting, truncating, dropping one or more sounds; non-full voicing -ра-, -ла-, which corresponds to the modern -оро-, -оло-, lack of prosthesis. Among the word-forming and lexical archaic phenomena are those associated with the use of the prefixes ic-, i3-, B-, во-, воз-, вос, у-, од-, со-, су-; suffixes -ець- and -ник-; component много. It has been found that in "Eneida" there are many lexical and morphological archaic phenomena associated with the use of the obsolete verb personal form of the present tense єсть; suffix -ова-instead of -ува-, -юва; archaic infinitive forms on -ть; forms of personal verbs without ending; using the postfix -ся in verb forms; forms of the imperative mood with the unreduced ending -іте and -ім; personal verb forms of the reverse condition with the suffix -сь instead of -ся; postfix -ть in the form of the third person singular of the present tense; archaic forms of participles and gerunds; parallelism of personal endings of verbs in the first person plural: -мъ, -мо, -мы, -м, -ме, which developed after the decline of the reduced sounds. Common lexical and morphological archaic phenomena in the noun system include the use of obsolete noun forms with specific endings and suffixes; in the system of adjectives - the use of uncontracted full forms of adjectives (participles, ordinal numbers, indicative, definite and interrogative pronouns); the presence of contracted adjectives, verbs and pronouns; archaic case forms of adjectives; creating a analytical form of degrees of comparison of adjectives with the words «самий», «тяжко», «з диявола» and the suffix -ійш-. Archaic forms of pronouns, adverbs and auxiliary parts of speech that have fallen out of active use or survived in dialects.
Постановка проблеми. Традиційно вважають, що визначальну роль у становленні української літературної мови відіграв Іван Котляревський, котрий в основу письменницької творчості поклав середньонаддніпрянські говори, які розглядають основою й української національної, і літературної мови. Сьогодні літературна творчість зачинателя української літературної мови неодноразово ставала об'єктом наукових студій із мовознавчого, літературознавчого, культурологічного та етнографічного ракурсів. 
Зокрема, у 2015 р. у Львові вийшло друком комплексне синтетичне дослідження-монографія $€$. Нахліка, у якій автор підсумував, узагальнивши та переосмисливши, основні майже двохсотлітні здобутки в дослідженні літературної спадщини I. Котляревського й зауважив щодо мови його творів: «За часів, коли почав вправлятися у складанні віршів Іван Котляревський, перед ним відкривалося два шляхи: або писати українською народною мовою, себто живою, розмовною, за якою до того ж стояла багатюща фольклорна традиція, а також часткова апробація у так званих низьких жанрах попередньої літератури, або ж послуговуватися російською літературною мовою, якою друкувалася тодішня світська преса i на яку, внаслідок насильницьких заходів царизму, переходили вищі верстви української суспільності. Цими двома шляхами він і пішов у своїй довголітній літературній діяльності: спочатку першим, звичнішим для нього, а потім пробував іти також другим» [1, с. 21]. Загалом дослідник зазначив, що «на час травестування «Енеїди» (починаючи від 1790-х рр.) староукраїнська літературна мова вже практично зникла, точніше, була усунута 3 активного вжитку в підросійській Україні. Він застав лише уламки тої книжної (писемної) мови, 3 яких і насміхався в комічній опері «Наталка Полтавка», відтворюючи канцелярський жаргон Возного» [7, с. 21]. Отже, у руслі таких поглядів щодо тогочасного стану української мови нам видається актуальним завданням дослідити наявність архаїчних граматичних рис в «Енеїді» I. Котляревського.

Аналіз досліджень. Безпосередньо мова літературних творів І. Котляревського була предметом досліджень вітчизняних мовознавців у різні роки. Так, М. Пилинський досліджував мову i стиль «Енеїди» [2]; Ю. Шевельов аналізував лексику його творів 3 позиції традицій і новотворів [3]. Внесок І. Котляревського у становлення української літературної мови в другій половині XVIII - першій половині XIX ст. став предметом дослідження М. Лисинюк [4]. Г. Буткова проаналізувала внесок І. Котляревського у розвиток нової літературної мови на фоні загальнокультурних особливостей доби межі XVIII-XIX ст. [5]. У загальнокультурному контексті проаналізував творчість письменника Г. Степаненко [6] та ін.

Водночас аналіз фахових джерел засвідчив, що в останні роки значно зріс інтерес до дослідження архаїчних рис творів представників українського письменства. Зокрема, Л. Павленко проаналізувала особливості функціонування граматичних архаїзмів у творчості Т. Шевченка [7]. Лексико-семантичні поля і групи лексичних архаїзмів у літературній спадщині I. Нечуя-Левицького стали предметом дослідження Ж. Колоїз [8]. Н. Баран- ник виділила й охарактеризувала низку архаїчних груп лексики в романах С. Стороженка [9]. I саме іiі типологію ми взяли в основу аналізу архаїчних граматичних рис в «Енеїді» I. Котляревського.

Метою статті $\epsilon$ аналіз особливостей граматичних архаїзмів у поемі І. Котляревського «Енеїда» на основі їх поділу на лексико-фонетичні, лексико-словотвірні та лексико-морфологічні архаїчні явища.

Завдання статті визначаються іï метою і полягають у виявленні історично маркованої лексики та їі систематизації за граматичними проявами.

Об'єктом дослідження є лексика поеми I. Котляревського «Енеїда», а предметом - фонетичні, словотвірні й морфологічні архаїзми в іії складі.

Виклад основного матеріалу. Серед низки визначень поняття архаїчності нам найбільше імпонує сформульоване Г. Гайдукевич: «Архаїчними $є$ слова, що позначають актуальний для даної мовної спільноти референт, але характеризуються ізольованістю фонетично-графічної, морфологічної, словотвірної чи лексико-семантичної форми на тлі сучасної мовної системи, внаслідок чого в їхній семантичній структурі вирізняється сема «архаїчний», яка відносить їх на периферію лексичного складу мови, з одного боку, та на периферію відповідного синонімічного гнізда, з другого, і надає йому експресивної конотації у мові та виразної стилістичної функції у тексті» [10]. Граматичні архаїзми ілюструють передусім збереження давніх особливостей формотворення, словозміни, відмерлих граматичних категорій, i в сучасному мовознавстві їх прийнято розподіляти на лексико-фонетичні, лексико-словотвірні та лексико-морфологічні архаїчні явища [9, c. 202].

Аналіз лексики поеми «Енеїда» засвідчив, що до найбільш виражених лексико-фонетичних архаїчних явищ можемо зарахувати ті, що пов'язані з видозміною певних звуків у словах, у яких «на сучасному етапі вони мають дещо інше фонетичне оформлення. До цієї групи належать застарілі слова, які характеризуються, в основному, чергуванням звуків, усіченням або, навпаки, вставлянням одного або двох звуків, у результаті чого слово, маючи відповідник у сучасній мові, набуває іншого, відмінного звучання застарілості» [9, с. 211]. Серед найбільш частотних в аналізованому творі лексико-фонетичних явищ виділимо такі: 1) чергування голосних звуків: «Потім з підлевою індик» [11, с. 23]; «По локоть руки засукав» [11, с. 44]; «К війні, в яку їх злость веде» [11, с. 134]; «3лость, кажуть, сатані сестриия» [11, с. 157]; «Поставить, як іти в поход» [11, с. 151]; «За нею рани, смерть, увіччя, Безбожность $і$ безчоловіччя» [11, с. 134]; «3а те в немилость і попала» [11, с. 159]; «Завзятость 
всіх опановала, Тут лютость всіма управляла» [11, с. 179]; «Без битой голої копійки» [11, с. 135]; «Позволь тіла убитой раті, Як водиться землі предати» [11, с. 208]; «Еней на бой його лиш просить, I так би й кончилась війна» [11, с. 211]; «Побачимо те в п'ятой часті» [11, с. 140]; «Війна в кровавих ризах тут» [11, с. 134]; «Війни кривавой не страшися» [11, с. 143]; «Тут люд був разних язиків» [11, с. 139]; «I разні пісні підняли» [11, с. 161]; «Там разний гомін з стукотнею» [11, с. 175]; «Шатнулись, разних трав нарвали» [11, с. 223]; «Все вешталося, все кишало» [5, с. 219]; «Біда не по дерев'ях ходить» [11, с. 141]; «Сднаково ж сам не плошайся» [11, с. 143]; «Блакитне полом'я взвилось» [11, с. 159]; «Як знахурі, чуже толкуєм» [11, с. 167]; «Павидла, сала, осятрини» [11, с. 213]; приголосних звуків: «I мусила їй обіщати/» [11, с. 159]; «B чиновні вивесть обішавв» [11, с. 165]; «Хоть молоді були та гожі» [11, с. 162]; «I нову Трою защищцати» [11, с. 173]; «I діло Турна защищцав» [11, с. 211]; «На перву ритулян попитку» [11, с. 173]; «До сього часу» [11, с. 182]; «I виполнивши всі обряди, Латин прорек такий приказ» [11, с. 212] тощо; 2) фонетичні форми зі збереженням звука, замість якого в сучасній мові виступає інший. Так, на місці новозакритих складів сьогодні вживаємо $i$ замість $о$, відтвореного в поемі: «Кусала ногті на руках» [11, с. 34]; «Бо послі, чуєш. Нічичирк!» [11, с. 18]; «Тодi від мене возьмеш чвирк» [11, с. 19]; «Тут їли рознії потрави» [11, с. 23]; «Ночною се було добою» [11, с. 35]; «I весь проворний чесний род» $[11$, с. 87]; «I в самий итурхобочний бой» $[11$, c. 125]; «A все то хитрость єсть жіноча» [11,с.148]; «А вас, Анхізович, покорно Прошу Палланта доглядать» [11, с. 151]; «Но пред Іулом прослезивсь» [11,c.166]; «I убирались на простор» [11, с. 169], «В бою стояли у ворот, I боронили в кріпость вход» [11, с. 180]; «Hе сnас ні росm, ні сила многа» [11, с. 181]; «Возьміть назад свої гостинціi» [11, с. 213]; «Mессап же мусить підкрепляти» [11, с. 216]; «Нехай своӥх держаться слов!» [11, с. 217]; «I байдуже - ні сльоз, ні слов» [11, с. 219]; «Боль рани зараз уняло» [11, с. 223]; «Утихомирясь, стали в строй» [11, с. 227]; 3) усічення, випадання одного або кількох звуків: «Як амуницю спорядили» [11, с. 132]; «Пред страшним воїном гряде» [11, с. 137]; «I лошаків мінять охоч» [11, с. 137]; «Чрез тебе сили набираєм» [11, с. 142]; «Тогді не буду жить чрез силу» [11, с. 152]; «Нехай Зевес вам помога» [11, с. 153]; «Еней тожс по лісу бродив» [11, с. 153]; «К Лависі од любві був в горі» [11, с. 155]; «А послі Ремових він воїв По одному всіх подушив» [11, с. 167]; «Рутульиі зрять - навстяж ворота» [11, с. 180]; «Якмога швидше уби- равсь» [11, с. 181]; «Без зву к нам в гості нав'язався» [11, с. 182]; «Велить явитись пред собою» [11, с. 112]; «Таким тебе зна наша Січ» [11, с. 112]; «І хан сказав так, не сумнись» [11, с. 212]; «Коли Еней мене бажа» [11, с. 215]; «Народ, як черв, заворушивсь» [11, с. 216]; «А Турна повстрічать бажа» [11, с. 223]; «Безсмертного хто ж ма убити?» $[11$, с. 220] та ін.; 4) вставляння одного чи кількох звуків: «Прощчайсь навік тогді з порядком» [11, с. 47]; «І кров христьянську замовляти» [11, с. 53], «Які письменнійші із них» [11, с. 134]; «I сами о світі не знались» [11, с. 135]; «Як доля против нас яриться» [11, с. 141]; «Тут будеть град над городоми» [11, с. 143]; «Евандр ияар добрий, я чував» [11, с. 145]; «Блакитне полом'я взвилось» [11, с. 159]; «Реветь, і душу іспускаєть, І воздух грімом наполняєть» [11, с. 181]; «Латинськї посли ззиркнулись» [11, с. 209]; «Против Енея не храбруйте» [11, с. 212], «Либонь, $i$ під руку ведеть» [11, с. 223]; «Зцілющчої води примчали» [11, с. 223] та ін.; 5) неповноголосся -ра-, -ла-, що відповідає сучасному -оро-, -оло-: «Латинці $і$ мені враги» [11, с. 146]; «Умом $i$ храбростю своєю» [11, с. 151]; «Крилатая, 3 сім'ю главами» [11, с. 154]; «Осрамлена моя гора!» [11, с. 160]; «У главной башти на сторожі» [11, с. 162]; «I заступайте від вражжи» [11, с. 166]; «Похвастать храбростю своєю» [11, с. 169]; «Навіки милий глас умовк» [11, с. 172]; «Против Енея не храбруйте, /» [11, с. 212] та ін.; 6) уживання слів без протетичних приголосних: «Сорочка, зв'язана узлами» [11, с. 73]; «Палав огонь, великий страх!» [11, с. 77]; «I саме ухо прехихе» [11, с. 97]; «Еней наш насторочив уха» [11, с. 98]; «Зате узол дружелюбивий» [11, с. 126]; «I тілько одповідь мав дати» [11, с. 126]; «На улиці все $і$ жила» [11, с. 133]; «Ну, к чорту! Швидше охмеляйся» [11, с. 158]; «Купив би музі на охвоту» [11, с. 189].

Виділили також низку лексико-словотвірних архаїчних явищ, визначальними особливостями яких дослідники називають «їх відмінність від сучасних лексем-відповідників специфічними суфіксами та префіксами» [9, с. 210]. До зафіксованих граматичних архаїзмів такого порядку належать: 1) архаїчні префікси із- та ic- : «Прийшла Венера, іскривившись» [11, с. 20]; «Щоб ти се сам їй ізвелів» [11, с. 21]; 《Дідона рано ісхопилась, Як одяглись, то ізійшлися» [11, с. 26]; «Як швидко оком ізмигнеш» [11, с. 28]; «Неначе дурману із'ӥла» [11, с. 33]; «I так ісп'яна їи сказав: Нехай ізслизне твій Дарес» [11, с. 45]; «Іскорчившуюся в дугу. Ірися нею ізробилась» [11, с. 49]; «Сидии, мов демон, під водою, Ізморщившись» [11, с. 51]; «Коли ж був трус, як ізгадаю» [11, с. 62]; «Або $i$ волос ізігнать» [11, с. 62]; «Поб 'єм - іскореним їх род» [11, с. 126]; 
«Ізміг врага в яєшню зм'яти» [11, с. 220] та ін.; 2) префікси в-, во-, воз-, вос-: «Світилка Фебова взійила» [11, с. 173]; «Побігла з криком вокруг вала» [11, с. 174]; «Уул сердечно взвеселився》 [11, с. 180]; «Чрез неї вся латинь возстала» [11, с. 187]; «Вокруг себе все побиває» [11, с. 196], «Нікого вкруг себе не бачив» [11, с. 161]; «Аркадиі! Лииаря возьміте!» [11, с. 198]; «Уздрів се Турн, возвеселився» [11, с. 222] тощо; 3) префікс $y$-: «Чи чорт за душу удряпнув? /» [11, с. 127]; «Навильот умисли всі знає» [11, с. 155]; «Прийшла Цибеллу умоляти» [11, с. 159]; «I убирались на простор» [11, с. 169], «Навіки милий глас умовк» [11, с. 172]; «Умазать морду їх мазкою» [11, с. 175]; «Но як же сильно удивився» [11, с. 182]; «I до того вас укараю» [11, с. 184]; «Не маю я ушановання; Ось як богинь я украдаю» [11, с. 184]; «Ув'яв Паллант, судеб по волі〉 [11, с. 198] тощо; 4) префікси о-; од-: «Та пан Еней наш опізнивсь» [11, с. 90]; «I на гіния свого озлився» [11, с. 126]; «I в руки всіх оддать катам» [11, с. 128]; «Зевес ій оддавав повагу» [11, с. 159]; «Одкиньте страх $i$ не робійте» [11, с. 161]; «Разком на той світ одпровадим» [11, с. 161]; «Щоб я од земляка одстав» [11, с. 163]; 《Для його служби жсизнь оддали» [11, с. 164]; «Одваэнних стали обнімати» [11, с. 165]; «Оддать троянцям з баришком» [11, с. 173]; «Ми вас одучим, супостати, Чужії землі однімати» [11, с. 179]; «Або оддам вас на роботу» [11, с. 184] тощо; 5) префікс по-: «Но повстрічався з другом Низом» [11, с. 168]; «On'ять о битві помишляв» [11, с. 173]; «А князь ваш бідний що помислить?» [11, с. 183]; «Сказав Венул - не погнівись!» [11, с. 212]; «A потаїть богам обидно» [11, с. 218]; «В ритульський подоспіла строй» [11, с. 220]; «Що став похожим на верзун» [11, с. 227]; 6) префікс со-: «Не ви народ мій сотворили» [11, с. 185]; 7) суфікс -ник: «Iул, Енеїв як наслідник, Похвальну рачію сказав; I свій палаш, щзо звавсь побідник, До боку Низа прив'язав» [11, с. 165]; «Як втопленик, посинів ввесь» [11, с. 214]; 8) префікс су-: «I супротивних потрошив» [11, с. 199]; 9) структурний компонент много-: «Услиш Венеру многогрішну!» [11, с. 187]; 10) суфікс -ець: «Нехай спиха Латина з стульця» [11, с. 229].

Проте, як засвідчив аналіз, найбільшого вияву в «Енеїді» набули лексико-морфологічні архаїчні явища, «як правило, різні частини мови, які дещо по-іншому були виражені в далекому минулому» [9, с. 210]. Найбільше таких граматичних архаїчних явищ ми виділили в системі дієслівних форм і категорій, а саме: 1) уживання застарілої особової форми теперішнього часу дієслова бути $\epsilon с \mathrm{c}$ : «Що од Енея єсть посли» [11, с. 111]; «Який між ними ссть уклад» [11, с. 118], «Який пройдисвіт єсть Еней» [11, с. 122]; «Паллант мій ваш єсть атаман» [11, с. 151]; «Що нам всього миліме ссть» [11, с. 153]; «У тебе мати ссть старая» [11, с. 163]; « « ісполин ссть черв і прах» [11, с. 181]; «Він діло єсть руки твоєй» [11, с. 186]; «Така підданиів єсть любов» [11, с. 196], «Що з Турном дружба ссть пуста» [11, с. 202], «Мужича правда ссть колюча» [11, с. 202], «Де діти ссть такї̈» [11, с. 212]; «I смерть моя вам ссть потіха, Душа моя не єсть чужа» [11, с. 215]; «Судьби єсть воля» [11, с. 218] тощо; 2) суфікс -ова замість -ува; -юва: «Щоб ӥй насумоватись всмак» [11, с. 35], «I тут стариів нагодовати» [11, с. 35], «Покуштовати стусанів?» [11, с. 41], «I тут вони не шановались» [11, с. 59], «Тарані торговав возами,...Уже в чім, бач, пораховати» [11, с. 53], «3а хліб подяковав, за сіль» [11, с. 55], «Еней-сподар посумовавши» [11, с. 58], «А які знали, то московських Вигадовали бриденьок. Як мандровав козак всю ніч» [11, с. 58], «Куди до пекла мандровати» [11, с. 60], «Еней сьому подивовався》 [11, с. 62], «При шведчині я дівовала» [11, с. 62], «Не люблять в пеклі жартовати» [11, с. 65], «Завзятость всім опановала» [11, с. 179] тощо; 3) архаїчні дієслівні інфінітивні форми на -ть: «3 собою стали розмовлять; Наӥлися $i$ прийнялися, Щоб по-вчорашньому гулять [11, с. 27], «Та ба! бач, треба покидать» [11, с. 32], «Досита щоб було всім їсть» [11, с. 32], «I стали тута оддихать. Далось $і$ їм троянців знать. Оп'ять забули горювать; Буває щзастя скрізь поганиям, $A$ добрий мусить пропадать» [11, с. 59], «Колись нам треба всім проnасть» [11, с. 64], «Послали до иаря сказать» [11, с. 59], «Царииімусим сю піднесть» [11, с. 116], «В чиновні вивесть обімав» [11, с. 165]; «Де усу буть, пушок мякенький» [11, с. 166]; «Убить і околіть готов» [11, с. 217] тощо; 4) форми особових дієслів без закінчення: «Аж не пізна вас дідько сам» [11, с. 75], «Мов чоловічий голос слуха» [11, с. 98]; «То так їі і вподоба» [11, с. 106]; «Про те Еней зна, молодець» [11, с. 116]; «Ритулець Турн тебе вже свата» [11, с. 120]; «Вельможі! Хто иаря не слуха» [11, с. 128]; «Турн побува у мене в жмені» [11, с. 145]; «К роботі приганя майстрів» [11, с. 150]; «На злеє всякий ма охоту» [11, с. 158]; «Коли в кошару завіта, Без крику мізок висмокта» [11, с. 168]; «I вся зоригнула старшина» [11, с. 215]; «Бо нею управля Зевес» [11, с. 226]; «На Турна міџно наступа, Тебе ніхто не захова» [11, с. 229] тощо; 5) уживання постфікса -ся в дієслівних формах: «I щоб $\kappa$ ним лучче підмоститься I пред Юноной заслужсться 》 [11, с. 41], «Еней не чув аж підошов, Хватаючися за ягою» [11, с. 72]; «До пекла навпростеиь прямуйся» [11, с. 55], «Та ну, на нас лиш придивися, - Сказала, - дуже не гнівися, Ось глянься...» [11, с. 75], «В Латиновій 
дочці добиться, Царя приданим поживиться» [11, с. 106], «Iду з Енесм поштурхаться, В мойх поступках оправдаться» [11, с. 217] «"Еней наш роздоброхотався》 [11, с. 40], «Сім кіп стоялася вона» [11, с. 56], «Збирать союзних поспішайся» $[11$, c. 156] тощо; 6) уживання форм наказового способу із нередукованим закінченням -ime в II особі множини «Підіть гіния мені кликніте, До мене зараз щоб прийшов, Глядіть же, иупко прикрутіте» [11, с. 29], «Беріте рать, idime з Богом» [11, с. 153], «А про війну $i$ в головах Собі ніколи не кладіте, $А$ мовчки в запічках сидіте» [11, с. 128], «3беріться, Турна окружіте, Гуртом, гуртом його напріте» [11, с. 183]; «Аркадиі! Лицаря возьміте! В ралещь к Евандру однеcime» $[11$, с. 198] тощо; 7) до мало вживаних сьогодні можемо зарахувати вживані автором особові дієслівні форми зворотного стану із суфіксом -cb замість -ся: "Чи се ж таки до діла робии, Що й досі тута загулявсь? Зевес не дурно похвалявсь» [11, с. 30], "Тут закурім, заженихаймось, Не розлучаймось ніколи» [11, с. 88] тощо; 8) уживання постфікса -mь у формі III особи однини теперішнього часу: «Ввесь знасть світ, щзо я не злобна» [11, с. 119], «Нехай твій шепчеть голосок» [11, с. 129] тощо; 9) інфінітив із постфіксом - $c b$ ц вживання в наказовому способі постфікса -ся: «I битися не поспішайся» [11, с. 218]; «I воюватись мали хіть» [11, с. 133] тощо; 10) усічені форми дієприслівників: «Сей, сидя на кормі, хитався» [11,с.57], «Та сидя люлечки курили» [11,с.57], «Як б’ють їх, не жалія поту» [11, с. 176]; «Другї лежа розмовляли» [11, с. 192]; «Еней, не милуя чванливих» [11, с. 205]; «Утихомирясь, стали в строй» [11, с. 227]; «Біду побачив неминучу» [11, с. 103], «Держась воєнного обряду Готовили заздалегідь» [11, с. 134], «Роздігшися, порозкладались» [11, с. 162]; «I часовї, на мушкетах Поклавшись, спали на заказ» [11, с. 167]; «То, зглянувшися між собою» [11, с. 228] тощо; 11) архаїчні форми дієприкметників і дієприслівників: «А панська на всі боки гнуча» [11, с. 212], «Терпівщих гіркую годину» [11, с. 146], «Еней, по човну походжая, На всі чотири розглядая» [11, с. 104], «В сій думизі смутно походжая» [11, с. 193], «Ютурна, кіньми управляя, Як од хортів лиса виляя》 [11, с. 224] тощо; 12) паралелізм особових закінчень дієслів у I особі множини: $-м ъ,-м о,-M b l,-м,-м е$, що розвинулися після занепаду зредукованих: «Виходь!»кричить. - Тічка подмімо, Нікого в поміч не просімо» [11, с. 05], «Уже ж вістимо всім богам» [11, с. 229], «То ми тобі таки щцось скажем, А може, в пекло шлях покажем» [11, с. 63], 13) наказова форма на -ім: «Тут закурім, заженихаймось» $[11$, с. 88$]$ тощо.
До найбільш поширених лексико-морфологічних архаїчних явищ у системі іменника належать такі: 1) застарілі іменникові форми зі специфічними закінченнями й суфіксами: «Веселлє в душу $і$ влилось!» [11, с. 155]; «На вал колоддя накотили» [11, с. 156]; «I злостію ввесь закипів» [11, с. 182]; «Товклись кулаччям по зубах» [11, с. 216]: Богиня з радім таниювала» [11, с. 229]; «Дала стариганю поклон» [11, с. 75]; «Сама з царицей горювала» [11, с. 34], «Іпред Юноной заслужиться» [11, с. 49], «Як під Бендер'ю воювали» [11, с. 58], «Хоть будуть голоса кричати» $[11$, с. 66], «Як під кислицей опинився» [11, с. 67], «Та знали церков щобб одну;... були в огні на самім дну» [11, с. 79], «В кип'ячих сіркой казанах» [11, с. 80], «Що їздили по ярмаркам» [11, с. 80], «Писарчуки поганих вірш» [11, с. 81], «Ніхто не гляне $і$ для сміха» [11, с. 88], «Або жмурили по куткам» [11, с. 97], «Тих переверне на звірей» [11, с. 102], «I все ходила павичом» [11, с. 106], «Гадюкой в серие поповзла» [11, с. 119], «Достав од Турна по усам» [11, с. 122], «Коли я тішився війной?» [11, с. 127], «Щоб військо йшло піठ коругов» [11, с. 129], «Всіх злостей випустивши жала» [11, с. 172] тощо. Такі форми засвідчують відголоски давньоруських парадигм, що часто передають архаїчні форми узгодження в роді та числі: «Багацько трупа там палилось» [11, с. 211] тощо; 2) архаїчні форми знахідного й орудного відмінків однини іменників жіночого роду давніх -ā- (-jā-), -̌̄- основ, а також форми орудного відмінка однини іменників жіночого роду, які утворилися в давньоруській мові за допомогою закінчення -ью (-ию), що поступово в писемних пам'ятках наступного староукраїнського етапу переросло у флексією -y (-ю): «За Смертію слідом валилось жінок, свекрух і мачух злих» $[11$, c. 71$]$ тощо; 3 ) представлені форми називного відмінка однини іменників середнього роду колишніх -јо̆-основ зі старою флексією - $\epsilon$ (-е): «Там всі невірні і христьяне, ...Була ту шляхта і міщане» $[11$, c. 81$]$ тощо; 4) форми орудного відмінка двоїни, що сьогодні зберігаються у вигляді флексії орудного відмінка множини -има парних іменників і субстантивів, а в попередні етапи розвитку літературної мови мали відмінкові закінчення -ами: «3 зажмуреними всі очами» [11, с. 80].

Значно ширше представлені архаїчні лексико-морфологічні явища в системі прикметника, серед яких ми виділили такі: 1) нестягнені повні форми прикметників (дієприкметників, порядкових числівників, вказівних, означальних i питально-відносних займенників): «Удавсь на всеє зле проворний» [11, с. 16], «Я все б зробив за сюю плату» [11, с. 18], «I страву всякую, без 
мови В голодний пхали все куток» [11, с. 20], «Тут їли рознії потрави» [11, с. 23], «Мізернії наклав дві скриньки» [11, с. 31], «Чи знав ти, що такеє гроші?» [11, с. 32], «Були щоб з вами злії болі» [11, с. 33], «Щоб горе злеє розказать» $[11$, с. 34], «Панове, знаєте, трояни. I всі хрещенії миряни» [11, с. 38], «I браги повнії діжки» [11, с. 39], «Трояниі волокли з собою Старую бабу, як ягу» [11, с. 49]; «Я добрую вам раду дам» [11, с. 49]; «Прокинься, милеє дитятко!» [11, с. 54]; «Він до тії прийтовши хати» $[11$, с. 60]; «Як вийшла бабище старая, Крива, горбатая, сухая〉 [11, с. 61]; «Не ангели - такії ж люди» [11, с. 64]; «Якессь дерево росте; На нім кислиці не простії, / Ростуть - як жар, всі золотії» [11, с. 65]; «В лісную гущу і пішов» [11, с. 66]; «Як ось пред якуюсь гору Прийшли» [11, с. 69]; «Якіїсь злидні щее стояли, Се все десяцькі та соцькії, Начальники, n'явки людськії» [11, с. 71]; «Ось глянься, щчо оце такеє! Оие деревие, бач, злотеє» [11, с. 75], «Там чути жсалобнії крики» [11, с. 79], «Пішов в другії ворота» [11, с. 85], «I вибивать царськую хату Либонь, покликали Ахмату» [11, с. 112], «Которую сам добре знаєш» [11, с. 163]; «Як травка, скоченая в полі» [11, с. 198], «В коротке мировеє врем'я Латинське і троянське плем'я Було як близькая рідня» [11, с. 210]; «В таку щасливую годину Еней чимдуж спис розмахав» [11, с. 230], «Ти будеш за сіє спасенний» [11, с. 230], «I мову слезную рече» [11, с. 231] тощо; 2) стягнені прикметникові, дієприкметникові та займенникові форми; «I розвела пожар чимал» [11, с. 35]; «Ta світ мені сей став не мил» [11, с. 232]; «B такім наряді влізши в хату» [11, с. 29]; «Зо всей одежі роздяглась» [11, с. 35]; «Не мил тобі уже десь світ?» [11, с. 65]; «Як ииган, смуглой иери був» [11, с. 73]; «Хто чим багат, то тим і рад» [5, с. 94]; «Сей переряжен в обезяну, I осужден людей смішить» [11, с. 103]; «Не шаблею ж убит i Авель» [11, с. 132]; «Хтоо тяглий, кінний, хто же niш» [11, с. 132], «Щоб битися, то рад летіть» [11, с. 133]; «Бог милостив для грішних всіх» [11, с. 147]; «Все рад робити для тебе» [11, с. 149] тощо; 3) архаїчні відмінкові форми прикметників, зокрема й із розряду відносних: «Hіхто сердеги не рятує Із рук троянська силача!» [11, с. 228], «Біда з злословими бабами!» [11, с. 229], «Олімпські нами управляють» [11, с. 230], «I мову слезную рече» [11, с. 231], «Взяла кораблик бархатовий» [11, с. 26], «По нашому хохлацьку строю \» [11, с. 29], «Що наші гречеські ковбаси! /» [11, с. 106], «Що не доспиш петрівськой ночі» [11, с. 106], «В послідній раз Сульмон зіва» [11, с. 171]; «I од ритульська стратилата» [11, с. 181] тощо; 4) творення складної форми ступенів порівняння якісних прикметників за допомогою слів «самий», «тяжкко», «з диявола»:
«I самі гарнії приправи» [11, с. 23], «I самой тихою порою» [11, с. 35], «Великий тяжко був пожар» [11, с. 35], «3 диявола швидкі, проворні» [11, с. 59], «І самих злійших нам врагів» [11, с. 146], «У самих храбрійших троян» [11, с. 182]; 5) творення вищого ступеня прикметників за допомогою префікса ic- і суфікса -ійш-: «Ісквапнійший за всякі штуки» [11, с. 103]; «Здававсь гірчійший їй від периюю» [11, с. 16], «Ось привезли і мальовання Роботи первійших майстрів» [11, с. 112], «Крикливійша із щебетух» [11, с. 118], «Яхиднійша од всіх відьом» [11, с. 118], «Там грудь сильнійша од гармат» [11, с. 169], «Що ми трусливійші жидів» [11, с. 183]; «За внуків славнійших дідів!» [11, с. 183]; «А ти, Латине, всіх блахійший, Прибав Енею дар смачнійший» [11, с. 214] тощо. Аналогічно творяться ступені порівняння прислівників: «Далеко тяжко в ліс забравсь» [11, с. 67], «Гребли з диявола всі дружно» [11, с. 101] тощо.

Чимало архаїчних форм в «Енеїді» пов'язано 3 уживанням займенників: «Ночною се було добою, I самой тихою порою» [5, с. 35], «Здоров, синашу, ма дитятко» [11, с. 35], «А сами мовчки одступили» [11, с. 113], «Скрізь прослана була ряднина До самой хвіртки від воріт» [11, с. 113], «Царииі мусим сю піднесть» [11, с. 116], «Мні мила ваша вся громада» [11, с. 116], «Потямить, якова-то я» [11, с. 118], «Ізгинеш од руки моєй!» [11, с. 122], «Од злості, з хмелю ввесь трусився» [11, с. 122], «В сіс-то нешасливе врем'я» [11, с. 125], «I казку мні скажи такую, Якой іще ніхто не чув/» [11, с. 129], «Щоб ложку, казанок всяк мав» [11, с. 129], «Своєй отчизни для сторожі» [11, с. 133], «Тілесні сили в кім охляли, В тім дух не швидко, та замре» [11, с. 143], «Забувши о біді своєй» [11, с. 148], «Що получала во дні они» [11, с. 174]; «Богів се воля! Вірте мні» [11, с. 161]; «Мовляв (нехай покой му вічний)» [11, с. 163]; «То і повинен жить для ней» [11, с. 163]; «В безпечності не сподівались Hi од кого ніяка зла» [11, с. 166]; «Щоб мні ритульиів розідрать» [11, с. 175]; «Дай поміч мні стишок зложить!» [11, с. 175]; «Над всіми остававсь начальний» [11, с. 183]; «Щоб сильною своєй рукою» [11, с. 219]; «Хоть в віщц хоч перекидайся» [11, с. 230] тощо.

Наявні в поемі числівникові архаїчні форми: «Мезап, Галес в орухім отряді» [11, с. 156]; «На перву ритулян попитку» [11, с. 173]; «Троян багацько подушила» [11, с. 177]; «А вас тут стілько, боїтесь» [11, с. 183]; «Юнона в первий раз смирилась» [11, с. 229], «Крилатая, з сім'ю главами» [11, с. 154].

Архаїзація проглядає й у ситуаціях неузгодженості роду іменника та числівника: «Одна дівча була гостренька» [11, с. 97] тощо. Трапляється вживання архаїчної двоїни: «Він мав на голові дві mвapi» [11, c. 134]. 
Частотними $\epsilon$ архаїчні форми прислівників: «Ануте, нуте, йдіте швидче» [11, с. 42]; «Нігде од неї не ввильнув» [11, с. 117]; «Побачив люду скрізь багацько» [11, с. 126]; «Бояри вмиг скомпоновали» [11, с. 129]; «Цибелла перше закректала, А послі кашлять начала» [11, с. 160]; «Тебе прогонять відсіля" [11, с. 161]; «А послі Ремових він воїв По одному всіх подушив» [11, с. 167]; «Що й очі вискочили преч» [11, с. 167]; «Вблизі тут був намет Серрана» [5, с. 167]; «Пора нам відсіль уплітати» [11, с. 168]; «Ox! Чом не звір я, чом не львиия?» [11, с. 175]; «I тут начав щцосил кричати» [11, с. 179]; «I вовся 3 ніг його зиибає» [11, с. 182]; «Щоб преч із кріпості втікать» [11, с. 183]; «Вдень п'яні сплять, а крадуть вніч» [11, с. 185]; «Відкіль же Турн тут притуливсь?» [11, с. 186]; «Бо нігде рифм уже достать» [11, с. 189]; «Кричать, біжать, сniшать якмога» [11, с. 189]; «Що так негречі кличе к бою» [11, с. 203]; «А в смутний час навтікача!» [11, с. 214]; «Коли б пан Феб од перепою Заранше в воду не заліз» [11, с. 217]; «Богині в гніві также баби» [11, с. 188]; «Тепер дівчат хоть гать гати; Тепер на сей товар не скудно» [11, с. 218]; «Сперва тихенько, послі вглас» $[11$, с. 220]; «Все вмиг зробилось кулішем» [11, с. 220]; «Мов галка, нарядилась вмах» [11, с. 227]; «Ти зла їм вдоволь задала» [11, с. 229], «Енею глуздівно сказав» [11, с. 230] тощо.

Характерною для мови поеми «Енеїда» $\epsilon$ велика кількість застарілих форм прийменників, сполучників, часток: «Мене боги к тобі послали» [11, с. 54], «I жарили зо всіх боків» $[11$, с. 78], «Ходім лишень $к$ моїй господі〉 [11, с. 96], «К чому $i$ як Еней щасливий» [11, с. 97], «Подумать о біді своєй» [11, с. 103]; «Послів повів к иарю з пихою» [11, с. 113]; «Еней по шастю без поміхи Вдавався в жарти, ігри, сміхи, А о Юноні і забув» [11, с. 117]; «Робила об собі лепорт» [11, с. 118]; «I зараз лист послав к Енею» [11, с. 122]; «Як тілько к пам'яті вернулась» [11, с. 124]; «Зізвав к собі панів вельможних» [11, с. 127]; «Хто ж о війні проговориться» [11, с. 128]; «К присязі зараз привели» [11, с. 129]; «Перед себе списи наставлять» [11, с. 130]; «I гасло всім к війні дає» [11, с. 134]; «К роботі приганя майстрів» [11, с. 150]; «К Лависі од любві був в горі» [11, с. 155]; «3 плосилку гнися хоть в дугу» [11, с. 157]; «Нетленнії од рода в род» [11, с. 160]; «А о повинності мовчиш» [11, с. 163]; «Обнявшись со Евріалом-земляком» [11, с. 164]; «Прокрастить можна поуз стан» [11, с. 165]; «I самачно по вечері спав» [11, с. 167]; «I од землі туман піднявся» [11, с. 169]; «Об мертвих вість скрізь пронеслася» [11, с. 173]; «I спорить о своїх правах?» [11, с. 191]; «О смерті князя всі ридали» [11, с. 198]; «По серию ӥм ся річ була» [11, с. 209];
«Прокинь к Лавинії любов» [11, с. 214]; «Гіния к Енею посилає» [11, с. 219]; «Еней од рани шкандибає» [11, с. 222]; «Либонь, $і$ під руку ведеть» [11, с. 222]; «Я, далебі, дурна була» [11, с. 229], «Не тебе, далебіг, боюсь» [11, с. 230] тощо.

Отже, проведений аналіз граматичних архаїзмів у складі лексики поеми I. Котляревського «Енеїда» засвідчує, що автор, користуючись для іiі написання селянською говіркою свого краю, «простонародною» мовою, досить активно використовував фонетичні, словотвірні та морфологічні архаїчні риси, що засвідчує тяглість традицій формування української народної мови, а на її основі - літературної.

Водночас аналіз лексики поеми підводить до розуміння досить помітних впливів на ії склад панівної на той час російської мови, що знайшло свій відбиток і в мові «Енеїди» на лексичному й граматичному рівнях і що може стати предметом подальшого аналізу.

\section{ЛITЕРАТУРА}

1. Нахлік Є.К. Перелицьований світ Івана Котляревського: текст - інтертекст - контекст / наук. ред. В. Панченко ; НАН України. ДУ «Інститут Івана Франка». Львів, 2015. 543 с.

2. Пилинський М.M. Із спостережень над мовою і стилем «Енеїди» I. Котляревського. Мовознавство. 1988. № 5. С. 25-29.

3. Шевельов Ю. Традиція і новаторство в лексиці і стилістиці І.П. Котляревського. Чернівці : Рута, 1998. 78 с.

4. Лисинюк М.В. Внесок представників письменства у становлення української літературної мови (друга половина XVIII - перша половина XIX ст.). Питання культурологіï. Вип. 34. URL: file://C:/Users/user/Downloads/ Pk1_2018_34_12.pdf (дата звернення: $10 . \overline{0} 6.202 \overline{1})$.

5. Буткова Г.В. Мова і культура: продукт історії. URL: http://dspace.nbuv.gov.ua/bitstream/handle/ 123456789/93862/26-Butkova.pdf? sequence $=1$ (дата звернення: 22.07.2021).

6. Степаненко М. Мовотворчість Івана Котляревського. Зоря Полтавщини. 19.03.2019. URL: http://zorya.poltava.ua/movotvorchistivana-kotljarevskogo/ (дата звернення: 04.07.2021).

7. Павленко Л. Граматичні архаїзми у творчості Тараса Шевченка. Волинь філологічна: текст i контекст: збірник наук. праць: Творчість Т. Шевченка: традиції і сучасність / упоряд. I. Мельник. Луцьк : Східноєвроп. нац. ун-т ім. Лесі Українки, 2014. Вип. 18. C. $318-328$.

8. Колоїз Ж. Лексичні архаїзми у творчій спадщині Івана Нечуя-Левицького. Філологічні студіі. Науковий вісник Криворізького дер- 
жавного педагогічного університету. 2009. Вип. 3. С. $68-81$.

9. Баранник Н.О. Архаїзми в романах С. Скляренка «Святослав», «Володимир». Література та культура Полісся. Серія «Філологічні науки» : збірник наук. праць Ніжинського державного університету імені М. Гоголя. 2019. № 96. № 13. С. 202-213.

10. Гайдукевич Г. Історизми та архаїзми як основні виражальні засоби історичної стилізації. URL: http://ekhsuir.kspu.edu/bitstream/ handle/ (дата звернення: 14.07.2021).

11. Котляревський І. П. Енеїда : Поема; Наталка Полтавка : П'єса: для серед. та ст. шк. віку / передм. та приміт. О.І. Гончара ; Післямова В.О. Шевчука. Київ : Веселка, 2000. 327 с.

\section{REFERENCES}

1. Nakhlik, Ye. K. (2015) Perelytsovanyi svit Ivana Kotliarevskoho: tekst - intertekst - kontekst [The transliterated world of Ivan Kotliarevsky: text - intertext - context] Scientific editor V. Panchenko; NAS of Ukraine. SI «Ivan Franko Institute». Lviv, 543 p.

2. Pylynskyi, M. M. (1988) Iz sposterezhen nad movoiu i stylem «Eneidy» I. Kotliarevskoho [From observations on the language and style of I. Kotliarevsky\&apos;s «Eneida»]. Movoznavstvo, № 5, pp. 25-29.

3. Shevelov, Yu. Tradytsiia i novatorstvo v leksytsi i stylistytsi I. P. Kotliarevskoho [Tradition and innovation in the vocabulary and style of I. P. Kotliarevskyi]. Chernivtsi: Ruta, 1998. $78 \mathrm{p}$.

4. Lysyniuk, M. V. Vnesok predstavnykiv pysmenstva u stanovlennia ukrainskoi literaturnoi movy (druha polovyna XVIII - persha polovyna XIX st.) [The contribution of representatives of literature in the formation of the Ukrainian literary language (second half of the XVIII first half of the XIX century)]. Pytannia kulturolohii, vol. 34. URL: file:///C:/Users/user/
Downloads/Pkl 201834 12.pdf (date of application 10.06.202 $\overline{1}$ ).

5. Butkova, H. V. Mova i kultura: produkt istorii [Language and culture: a product of history]. URL: http://dspace.nbuv.gov.ua/bitstream/handle/ 123456789/93862/26-Butkova.pdf?sequence=1 (date of application 22.07.2021).

6. Stepanenko, M. (2019) Movotvorchist Ivana Kotliarevskoho [Language art by Ivan Kotliarevskyi]. Zoria Poltavshchyny. 19.03.2019. URL: http://zorya.poltava.ua/movotvorchist-ivanakotljarevskogo/ (date of application 4.07.2021).

7. Pavlenko, L. (2014) Hramatychni arkhaizmy u tvorchosti Tarasa Shevchenka. [Grammatical archaisms in the works of Taras Shevchenko]. Volyn filolohichna: tekst $i$ kontekst: Collection of scientific works: Creativity of T. Shevchenko: traditions and modernity / compiler I. Melnyk. Lutsk : Lesia Ukrainka East European National University, vol. 18, pp. 318-328.

8. Koloiz, Zh. (2009) Leksychni arkhaizmy u tvorchii spadshchyni Ivana Nechuia-Levytskoho [Lexical archaisms in the creative heritage of Ivan Nechuy-Levytsky]. Filolohichni studii: Scientific Bulletin of Kryvyi Rih State Pedagogical University. 2009, iss. 3, pp. 68-81.

9. Barannyk, N. O. (2019) Arkhaizmy v romanakh S. Skliarenka «Sviatoslav», «Volodymyr» [Archaisms in S. Sklyarenko\&apos;s novels «Sviatoslav», «Volodymyr»]. Literatura ta kultura Polissia. № 96: Collection of scientific works of Nizhyn State University by M. Hohol. Philological Sciences Series, № 13, pp. 202-213.

10. Haidukevych, H. Istoryzmy ta arkhaizmy iak osnovni vyrazhalni zasoby istorychnoi stylizatsii [Historicisms and archaisms as the main means of expression of historical stylization.]. URL: http://ekhsuir.kspu.edu/bitstream/handle/ (date of application 14.07.2021).

11. Kotliarevskyi, I. P. (2000) Eneida: Poem; Natalka Poltavka: play: for middle and senior school age. Preface and notes by O. Gonchar; afterword by V. Shevchuk. Kyiv: Veselka, 2000. 327 p. 